\title{
Morphology Performance On Six Black Rice Accessions (Oryza Sativa L.) In M1 Generation Irradiated By Gamma Rays
}

\author{
Jujun Widian ${ }^{1}$, Siti Nurhidayah ${ }^{1 *}$, Sherly Rahayu ${ }^{2}$, Efrin Firmasnyah ${ }^{1}$, and Roza Yunita ${ }^{3}$ \\ ${ }^{1}$ Department of Agrotechnology, Perjuangan Tasikmalaya University, Tasikmalaya, West Java, 46115 Indonesia \\ ${ }^{2}$ Isotope and Radiation Application Center, National Nuclear Energy Agency of Indonesia, Jakarta, 12440, Indonesia \\ ${ }^{3}$ Department of Agrotechnology, Andalas University, Padang, West Sumatera, 25136, Indonesia
}

Article Info

Received:

26 February 2021

Accepted:

28 February 2021

Published:

10 March 2021

Competing Interest:

The authors have declared that no

competing interest exists.

Corresponding Author:

Siti Nurhidayah, Department of

Agrotechnology, Perjuangan

Tasikmalaya University, Tasikmalaya,

West Java, 46115 Indonesia

Email:nurbidayah.unper@gmail.com

(C) 2021 The Authors. This is an open access article under the CC BY license.

\begin{abstract}
The increasing of plant genetic diversity can be done through physical mutations with gamma-ray irradiation. This study aimed to determine the effect of gamma-ray irradiation on the growth of six M1 generations of black rice accessions. This research was conducted from May to October 2019 at the Experimental Rice Fields of Perjuangan University, Tasikmalaya, West Java. The materials used in this study were six black rice accessions from Tasikmalaya (PH, PH2, PH3, PH5, PH7, and PH8) without 0 Gy irradiation and M1 generation irradiated with $200 \mathrm{~Gy}$ gamma-ray. The results showed that gammaray irradiation reduced germination characteristics, seedling height, and flowering age. Some of the accessions showed different effects, there were a decrease and an increase in the characters of root length, plant height, number of productive tillers, number of unproductive tillers, and the total number of tillers.
\end{abstract}

Keywords: black rice, breeding, gamma-ray irradiation, morphology, mutation 


\section{Introduction}

Indonesia has many rice (Oryza sativa L.) varieties, one of the popular rice in the community is black rice. Black rice is consumed as a functional food because it is rich in nutrients such as amino acids, potassium, magnesium, calcium, iron, anthocyanin pigments, and flavonoids. Those nutrients can promote body health and increase resistance to disease (Suhartini and Suardi 2010). The economic value of black rice is high because it has higher properties and nutritional value compared to white and brown rice. Local rice that has been cultivated sustainably has the advantage of being able to adapt well to various specific land and climatic conditions (Kristamtini 2014; Sitaresmi et al., 2013). But, local rice has limitations that make its existence increasingly abandoned and threatened with extinction, including long-life (>145 days), a high posture that causes plants to fall easily, not resistant to pests and diseases, and low production (Toha et al., 2005).

Local rice characteristics improvement can be done through plant breeding activities. The most widely practiced traditional breeding methods are crossing or hybridization, but still have weaknesses such as accuracy and long-time requirements. Meanwhile, breeding through biotechnology can be carried out with several methods such as tissue culture and genetic engineering with the molecular marking approach and mutation utilizing gamma-ray irradiation. Mutations are changes that occur suddenly and randomly in genetic material at the level of the genome, chromosome, or gene (Aisyah, 2006; Lestari, 2012). Induced mutations are a proven way to cause diversity in plant varieties against desirable traits that cannot be expressed in original characteristics or lost during evolution.

The effect that will occur when inducing mutations is to increase the high diversity after irradiation. This is the only way that can be done to improve the diversity in sterile and apomixis plants. Mutations can also produce variety more quickly than conventional breeding. In addition to having several advantages, mutation breeding has several weaknesses, where the acquired traits are unpredictable and the instability of genetic markers that appear in the next generation. The decrease in plant height or plants becomes stunted due to the influence of high doses due to physiological disorders or chromosomal damage due to the effect of mutagens (gamma-ray radiation) given. This mutation was carried out to obtain the genetic diversity of black rice plants related to plant age to make it more early through mutation breeding (Syukur, 2000).

According to Sobrizal (2016), mutation breeding can effectively change a few traits without changing other characteristics that are already preferred. According to Rahayu et al. (2013) stated that after the induction mutation, the production ranged from 4.377.20 tons/ha compared to the Sarinah variety, which was 3.57 tons/ha altitude of $700 \mathrm{~m}$ above sea level. The optimum dose of gamma-ray radiation of the Cintana variety is around $200 \mathrm{~Gy}$. This study aimed to determine gamma-ray irradiation on the growth of six M1 generation black rice accessions.

\section{Materials And Methods}

\section{A. Time and place}

This research was conducted from July-November 2019 at the Experimental Rice Fields of the Tasikmalaya City, West Java, at an altitude of 350 meters above sea level.

\section{B. Plant material}

In this study, we used six black rice accessions originally from Tasikmalaya that collected by the Department of Agrotechnology of Perjuangan University. The germplasm namely PH1 (Cisayong 1), PH2 (Cisayong 2), PH3 (Tasikmalaya Regency Office), PH5 (Indihiang), PH7 (Rajapolah), and PH8 (Singaparna) (Nurhidayah and Umbara, 2019). We used black rice without irradiation ( 0 Gy) and M1 generation (irradiated with 200 Gy gamma-ray) because Warman et al. (2015) stated that 200 Gy gamma-ray radiation dose in black rice generation M2 could increase wide genetic diversity.

21 days after sowing, one seed per hole was planted at a distance of $25 \mathrm{~cm} \times 25 \mathrm{~cm}$. The seeds consisted of 6 accessions without gamma-ray irradiation $(0 \mathrm{~Gy})$ and 6 accessions resulting from the M1 generation of 200 Gy gamma-ray irradiation. Each accession was planted in a plot measuring $6 \mathrm{~m}^{2}$ with 3 replications so that the total area of the experimental field was about $288 \mathrm{~m}^{2}$.

\section{Observation variables}

The percentage of germination capacity (\%) was calculated from the number of live seeds divided by the number of seeds sown multiplied by $100 \%$. Seed height $(\mathrm{cm})$ measured from the base of the stem to the tip of the leaf, by straightening the plates upwards and expressed in $\mathrm{cm}$ at the age of 21 days after sowing (DAS). Root length $(\mathrm{cm})$, calculated by measuring the stem's base to the tip of the root. Measurements were made at the age of 21 HSS and expressed in units of $\mathrm{cm}$. Plant height $(\mathrm{cm})$ was measured from the soil surface to the tip of the flag leaves, is still upright at the age of 11 days after planting (DAP). The total number of tillers, namely the total number of tillers per clump at the age of 11 weeks after planting (WAP). The number of productive tillers, which is the number of tillers who are tolerant and measured at the age of 11 DAP. Flowering age (DAS) was calculated when the plants flower about 50\%. Then, t data obtained were calculated using descriptive analysis by calculating each treatment's mean value using Microsoft Excel.

\section{Results And Discussion}

\section{A. Germination}

The test results showed that black rice accessions without gamma-ray irradiation had germination power ranging from $79-97 \%$, while accessions irradiated with gamma rays had germination power of $72-90 \%$. A total 
of 5 accessions (PH1, PH2, PH3, PH5, and PH8) decreased their germination capacity after irradiation, except for $\mathrm{PH} 7$ accessions, which increased their germination capacity from $87 \%$ to $90 \%$. $\mathrm{PH} 2$ accession experienced the most considerable reduction in germination, which was $22 \%$. Meanwhile, PH3 accession experienced a decline in germination at least 2\% (Figure 1).
According to Sakin (1998), gamma rays harm the M1 generation. The percentage of the number of live seeds decreased with the increase in the mutagen concentration. The decrease in seed germination capacity was due to a deterministic effect due to gamma-ray irradiation. This causes a low rate of germination and seedling growth and can even cause death.

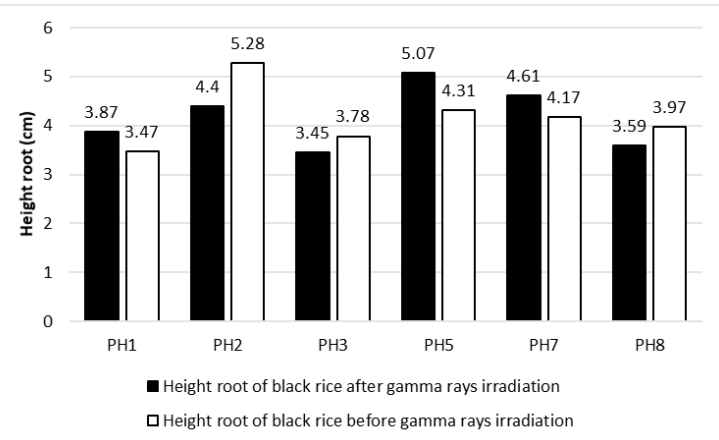

Figure 1. Percentage of black rice germination before and after gamma-ray irradiation.

\section{B. Seed height}

Based on Figure 2, the seed height growth for each accession is different. PH1 accessions before gammaray irradiation had seedlings about $20.48 \mathrm{~cm}$ taller than other accessions. Meanwhile, $\mathrm{PH} 3$ accession tended to be the shortest at around $18.11 \mathrm{~cm}$. High inhibition in each accession occurred in all accessions tested after irradiation. This was supported by the data that the accessions that had been irradiated with gamma rays were seen to experience seed growth inhibition in the height range 17.20-18.94 cm.

PH1 accession after irradiation had higher seeds compared to other accessions. This can be caused by genetic factors so that it has almost the same effect on rice plants' height. Of all accessions resulted in gamma-ray irradiation tends to decrease compared to without gamma-ray irradiation.

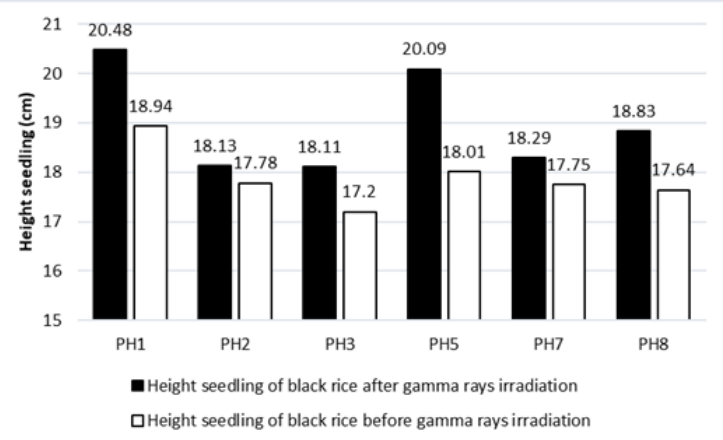

Figure 2. Height of black rice seedlings before and after gamma irradiation.

\section{Root length}

Figure 3 shows that PH5 had the longest roots before irradiation, and $\mathrm{PH} 3$ had the shortest roots. Meanwhile, after gamma-ray irradiation, $\mathrm{PH} 2$ accession had longer roots $(5.28 \mathrm{~cm})$, and PH1 accession had the most lacking roots $(3.47 \mathrm{~cm})$. Accessions PH1, PH5, and $\mathrm{PH} 7$ tended to shorten roots, while accessions $\mathrm{PH} 2, \mathrm{PH} 4$, and PH8 tended to become longer after being given gamma-ray irradiation.

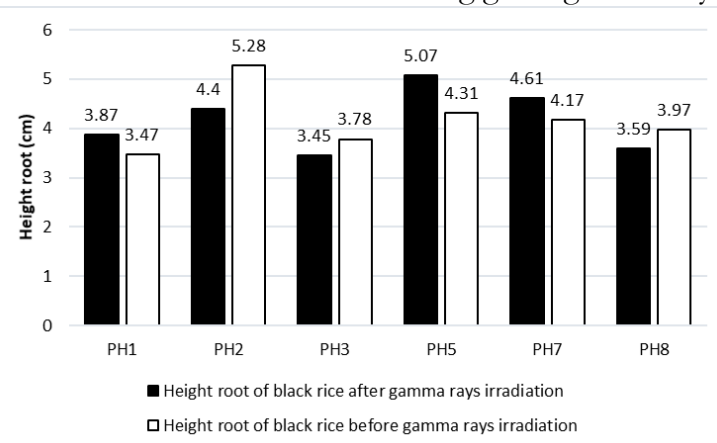

Figure 3. Length of black rice roots before and after gamma-ray irradiation. 
Gamma rays can also suppress the growth of roots, stems, and leaves (vegetative growth). Gamma radiation at too high a dose can directly affect plants. The higher the gamma radiation dose, the lower the plant's survival or growth; even higher doses, causes the plant to die. The radiation dose used to induce diversity is critical to the success of mutant plants. Giving too high a dose will inhibit cell division, which causes cell death, which affects the plant growth process and decreases plants' growth power and plant morphology. However, radiation doses that are too low are insufficient to mutate plants because the mutation frequency is too low to produce only a few mutated regions.

\section{Plant height}

Based on the morphological criteria for plant height issued by IRRI in 2012, it is divided into short $(<90$ $\mathrm{cm})$, medium (90-125), and tall $(>125)$ criteria. Plant height is classified as a somewhat important character, and this is because plant height dramatically affects the level of soil and efficiency in harvesting. If it is seen from Figure 4 that all accessions tested before irradiation are included in the moderate criteria, while after irradiation, one accession is in a short category $(88.2 \mathrm{~cm})$, and five accessions are in the medium category. The height distribution of the black rice plants tested had different results when seen from the research of Nurhidayah and Umbara (2019) that the black rice accession tested included high criteria with a height range of 129-137 cm. Environmental conditions influence this study, namely, the research was carried out in the dry season, and there was a drought to affect rice plants' growth.

Based on Figure 4, black rice paddy after irradiation gave a different response. Black rice accession experienced a high increase (PH1, PH2, and PH8) as much as 50\% and 50\% experienced shortening (PH3, PH5, and PH7). Reduced plant height or plants become stunted due to the influence of high doses as a result of physiological disturbances or chromosomal damage caused by mutagens (gammaray radiation) given. That the provision of gamma rays with high concentrations, in general, can reduce the percentage of plant growth.

The decrease in the rate of plant growth due to gamma-ray radiation is caused by a deterministic effect. The deterministic impact is the effect of cell death induced by radiation exposure (Aisyah, 2006). This arises because the radiation exposure dose given is above the threshold dose that should be received. The higher the radiation dose, the higher the deterministic effect. Plant height is a quantitative trait that is controlled by many genes. The character of plant height or a decrease in plant height is the most common indicator used to see mutagens' effects, both physical and chemical (Aisyah, 2006). In the study of Hanafiah et al. (2010), the impact of gamma-ray irradiation was to increase plant height at a dose of 20 $150 \mathrm{~Gy}$ and reduce plant height at a dose of $200 \mathrm{~Gy}$ in soybeans.

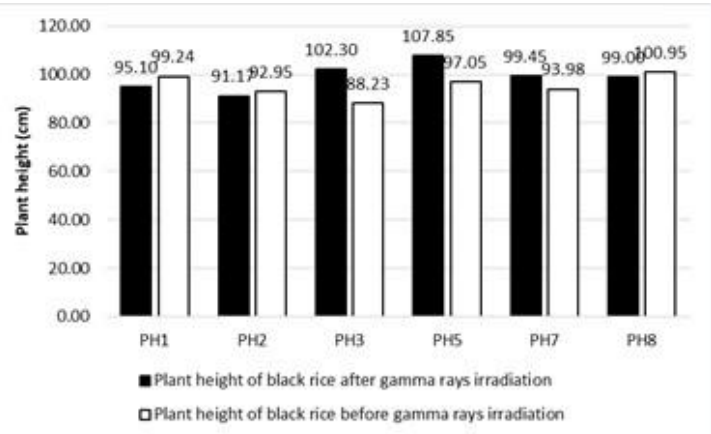

Figure 4. Distribution of mean height of black rice plants before and after gamma-ray irradiation.

\section{E. Number of tillers}

The number of productive tillers of accessions tested before gamma-ray irradiation ranged from 8-14 tillers, while accessions that had been irradiated with gamma rays ranged from 9 to 20 clumps (Figure 5.a). A total of 3 accessions (PH3, PH5, and PH7) experienced an increase in the number of tillers per cluster. Three accessions (PH1, PH2, and PH8) experienced a reduction in the number of tillers per clump after gamma-ray irradiation. In line with the research of Rahayu et al. (2020), there was a decrease in the number of productive tillers in the Mira-1 variety and Bestari variety after the M1 generation of 200 Gy gamma-ray irradiation dose treatment.

Before gamma-ray irradiation, accessions were in the range of 8-14 unproductive tillers and 9-20 unproductive tillers per clump (Figure 5.b). After gamma-ray irradiation, accessions $\mathrm{PH} 1, \mathrm{PH} 2, \mathrm{PH} 7$, and PH8 increased the number of tillers while PH3 and PH5 decreased the number of tillers per clump. After irradiation, PH3 accessions had fewer unproductive tillers (9 tillers) than PH8 accessions had more tillers, about 20 unproductive tillers per hill. A large number of unproductive tillers cause fewer rice yields. The photosynthate results that are inhibited from entering the grain (sink) result in fewer rice yields.

The total number of tillers of accessions tested before gamma-ray irradiation ranged from 13 to 18 tillers, while accessions that gamma rays had irradiated ranged from 13-24 tillers (Figure 5.c). After being irradiated with gamma rays, $\mathrm{PH} 8$ accessions had the most tillers, namely 24 tillers, while the lowest was PH3 accessions with an average of 13 tillers. 


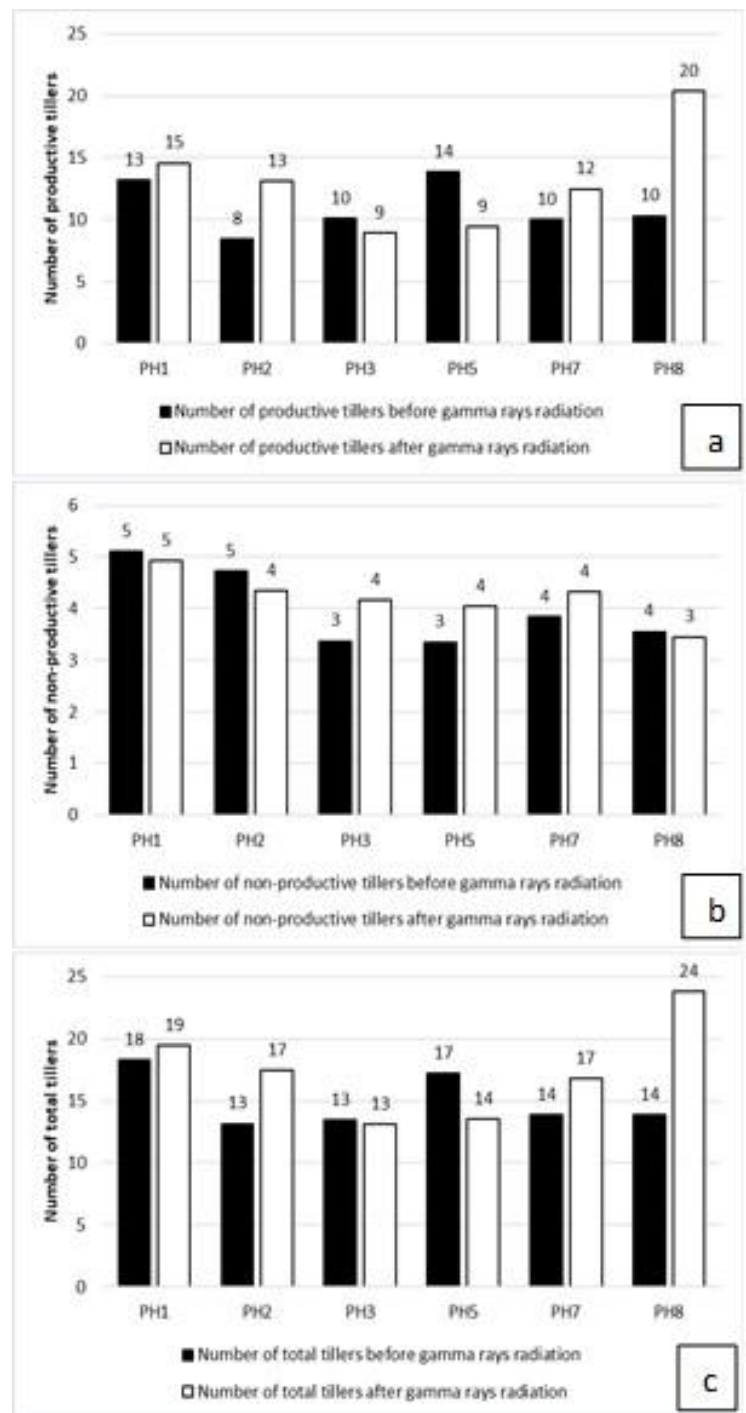

Figure 5. Distribution of the mean number of tillers per hill of black rice. a) productive tillers, b) unproductive tillers c) the total number of tillers per hill.

Figure 5 shows that the accessions PH1, PH2, $\mathrm{PH} 7$, and $\mathrm{PH} 8$ after gamma-ray irradiation experienced an increase in the number of tillers. In contrast to the accession $\mathrm{PH}, 5$ experienced a reduction in the total number of tillers. Meanwhile, PH3 accession did not change (13 children). The observation of the number of offspring showed that the results were not significantly different. The genotype that was initially homozygous changes to heterozygous so that the dominant gene's difference into a recessive gene remains covered by the dominant gene pair. Also, mutation treatment sometimes does not appear in the M1 generation but only seems in the M2 age and so on (Soedjono, 2003). This was also reinforced by Nurhidayah and Umbara (2019), who revealed that the total number of tillers of black rice was around 15-19 tillers. Soeranto (2011) states that mutations may not be directly expressed in the phenotype when the transformation occurs in a recessive direction and is in the heterozygous genotype structure, also known as silent mutation.

\section{F. Flowering age}

Based on Figure 6, black rice accessions before gamma-ray irradiation have a flowering age ranging from 74-89 DAS, while black rice accessions after gamma-ray irradiation range from 70-84 DAS. After being irradiated with gamma rays of all rice accessions, black rice tends to flower more quickly. The flowering of PH1 accession was faster, around 70 DAS, and the slowest PH3 acquisition was 84 DAS after irradiation.

The rapid age of harvest can be indicated by the quick age of flowering mutant plants from the observations carried out. It is that between the flowering period and the harvest age of the rice crop, there is a genuine positive correlation, where the more the flowering age, the deeper the harvesting age so that the flowering period can be used as a marker of the harvest age. The fast flowering of plants is due to genetic changes resulting from the induction mutations carried out. 


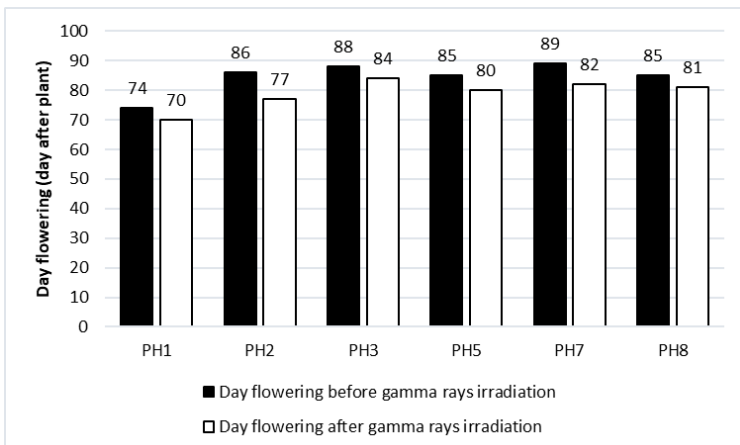

Figure 6. Flowering age of black rice before and after gamma irradiation.

\section{Conclusion}

All tested black rice accessions after gamma irradiation resulted in the most decline in the characteristics of germination, seedling height, and flowering age. Moreover, some of the accessions experienced a decrease and increase in the character of plant height, root length, and the number of tillers.

\section{Acknowledgments}

Gratitude is conveyed to the Institute for Research and Community Service, Universitas Perjuangan Tasikmalaya, which has fully funded this research through the Leading Research Scheme of the Study Program for the 2019 fiscal year with the contract number. 227/ST/LP2M/UP/08/2019.

\section{References}

[1] Aisyah S. I. 2006. Induksi mutagen fisik pada anyelir (Dianthus caryophyllus Linn.) dan pengujian stabilitas mutannya yang diperbanyak secara vegetatif. (Dissertation). Bogor, Institut Pertanian Bogor.

[2] Hanafiah D. S., Trikoesoemaningtyas, S. Yahya, and D. Wirnas. 2010. Induced mutations by gamma-ray irradiation to Argomulyo soybean (Glycine max). Nusantara Bioscience, 2:121125.

[3] Kristamtini, Taryono, P. Basunanda, and R. Murt. 2014. Keragaman genetik kultivar padi beras hitam lokal berdasarkan penanda mikrosatelit. Jurnal Agro Biogen 10(2): 6976.

[4] Lestari E. G. 2012. Combination of somaclonal variation and mutagenesis for crop improvement. J. Agro Biogen, 8(1): 38-44.

[5] Mugiono, Harsanti, L., and K. D. Azri. 2009. Perbaikan padi varietas Cisantana dengan mutasi induksi. A Scientific Journal for The Applications of Isotopes and Radiation, 5(2): 194-210.

[6] Nurhidayah S. D. S. and Umbara. 2019. Perbedaan komponen vegetatif dan generatif pada lima aksesi padi hitam (Oryza sativa L.) di Kecamatan Indihiang Tasikmalaya Jawa Barat. Journal of Applied Agricultural Sciences, 3 (1): 15-21.
[7] Rahayu S., V. Destavany, and Dasumiati. 2020. keragaan malai mutan padi generasi M1 hasil iradiasi gamma. A Scientific Journal for The Applications of Isotopes and Radiation, 16(2): 59-66.

[8] Rahayu S., A.K. Dewi, Yulidar, D. Wirnas, and H. Aswidinnoor. 2013. Analisis stabilitas dan adaptabilitas beberapa galur padi dataran tinggi hasil mutasi induksi. Jurnal Ilmiah Aplikasi Isotop dan Radiasi, 9(2): 81-90.

[9] Sakin M.A. 1998. The effects of different gamma-ray and ems doses on M1 and M2 generations in durum wheat (Triticum durum desf.). (Dissertation). Gaziosmanpasa University, Graduate School of Natural and Applied Science, Department of Field Crops. Tokat, Turkey.

[10] Sitaresmi T, R. H. Wening, A. T. Rakhmi, N. Yunani, and U. Susanto. 2013. Pemanfaatan plasma nutfah padi varietas lokal dalam perakitan varietas unggul. Iptek Tanaman Pangan, 8(1): 22-30.

[11] Sobrizal. 2016. Potensi pemuliaan mutasi untuk perbaikan varietas padi lokal indonesia. A Scientific Journal for The Applications of Isotopes and Radiation, 12(1): 23-36.

[12] Soedjono S. 2003. Aplikasi mutasi induksi dan variasi somaklonal dalam pemuliaan tanaman. Jurnal Litbang Pertanian, 22(2): 70-78.

[13] Soeranto. 2003. Peran iptek nuklir dalam pemuliaan tanaman untuk mendukung industri pertanian. Prosiding Pertemuan dan Presentasi ilmiah Penelitian Dasar IImu Pengetabuan dan Teknologi Nuklir P3TMBATAN Yogyakarta, 8 Juli 2003: 308-316.

[14] Suhartini T. and D. Suardi. 2010. Potensi beras hitam lokal Indonesia. Warta Penelitian dan Pengembangan Pertanian, 32(1): 910.

[15] Syukur S. 2000. Efek iradiasi gamma pada pembentukan variasi klon dari Catharantus roseus (L.) Don. Risalah Pertemuan Ilmiah Penelitian dan Pengembangan Teknologi Isotop dan Radiasi. Biochemistry Biotechnology Lab. Andalas University Padang. Padang. pages 33-37.

[16] Toha H. M., K. Permadi, Prayitno, and I. Yuliardi. 2005. Peningkatan produksi padi gogo melalui pendekatan model pengelolaan tanaman dan sumberdaya terpadu (PTT). Seminar Puslitbantan Pangan. Bogor. Badan Litbang Pertanian.

[17] Warman B, Sobrizal, I. Suliansyah, E. Swasti E, and A. Syarif. 2015. Perbaikan genetik kultivar padi beras hitam lokal Sumatera Barat melalui induksi mutasi. Jurnal Ilmiah Aplikasi Isotop dan Radiasi, 11(2): 125-136. 